\title{
Substance Abuse: Risk Factors for Turkish Youth
}

\author{
Andres J. Pumariega ${ }^{1}$, Hatice Burakgazi ${ }^{1}$, Ali Unlu ${ }^{2}$, Parna Prajapati ${ }^{1}$, Alican Dalkilic ${ }^{1,3}$
}

\section{ÖZET:}

Kimyasal madde bağımlıı̆ı: Türk gençleri için risk faktörleri

\begin{abstract}
Amaç: Kimyasal madde kullanımı gelişmiş ve Türkiye'nin da dahil olduğu gelişmekte olan ülkelerde artarak devam etmektedir. Bu büyüme kalkınma, globalleşme ve gençlik kültürü gibi güçleri de içeren pek çok faktörle ilişkilidir. Belirli toplumsal gruplarda gençlik kimyasal madde kullanımı risk faktörlerini tespit etme, engelleyici ve girişimsel stratejilerin geliştirilmesinde önemli bir yaklaşımdır.

Yöntemler: İstanbul'daki liselere kayıtlı 14-18 yaş grubundaki 31.272 gencin katıldığı, çeşitli kimyasal maddeler ve nüfus, sosyoekonomik, kültürel, psikopatolojik ve psikososyal risk faktörler hakkında bilgi içeren bir anketin verilerini analiz ettik. Avrupa Okul Anket Projesi (ESPAD), Avrupa'da Gençlik (YIE), ve $A B D$ 'de ki Geleceğin İzlenmesi ve Ulusal Hanehalkı Anketleri'ndekilere benzer sorular içeren bir anket uygulandı. Aşağıdaki her maddenin yaşam boyu kullanım risk faktörleri profillerini çıkarmak için ikili regresyon analizlerini kullandık: Tütün, alkol, esrar, diğer yasadışı uyuşturucular, ve çoklu (iki veya daha fazla) yasadışı uyuşturucu kullanımı.
\end{abstract}

Bulgular: Bu farklı madde kategorileri için istatistiksel olarak önemli risk profillerini belirledik. Bütün farklı risk faktör kategorileri geçit maddelerinin (tütün, alkol, esrar ve diğer uyuşturucular) kullanımına değişik derecelerde katkıda bulunurken, diğer uyuşturucu maddelerin çoklu kullanımı daha dar bir psikopatolojik (intihar, asabiyet ve antisosyal problemler) ve psikososyal (ailede madde kullanımı ve akran etkisi) değişkenler dizisi ile ilişkili bulundu.

Sonuç: Bulduğumuz risk profilleri farklı topluluklarda bulunan risk profilleri ile bazı ortak özellikleri paylaşmaktadır. Ancak, Türk gençlerinin bu özgün risk profilleri büyüyen kimyasal madde kullanım ve kötüye kullanım problemlerine yönelik primer ve sekonder engelleyici girişimler geliştirilmesinde yararlı olabilir. Türkiye'yi de içeren yükselen ülkelerin gençleri arasında, madde kullanımı zaman eğilimleri ve risk foktörlerine odaklanan kesitsel ve uzunlamasına çalışmalara intiyaç vardır.

Anahtar sözcükler: Türk gençleri, madde bağımlıı̆ı, ESPAD, lise öğrencileri, risk faktörleri

Klinik Psikofarmakoloji Bulteni 2014;24(1):5-14

\section{ABSTRACT:}

Substance abuse: risk factors for Turkish youth

Objective: Substance abuse amongst youth has been growing in developed and developing nations, including Turkey. This growth is related to a number of factors, not the least of which are forces associated with development, globalization, and youth culture. The identification of risk factors for youth substance abuse for particular populations is an important approach to the development of prevention and intervention strategies.

Methods: We analyzed the data from a survey of 31,272 youth ages 14 to 18 years enrolled in high schools in Istanbul that covered the use of various substances as well as a number of demographic, socioeconomic, cultural, psychopathological, and psychosocial risk factors. Our data consisted of answers to similar questions that were asked in European School Survey Project (ESPAD), Youth in Europe (YIE), and Monitoring of the Future Survey and the National Household Survey in USA. We used binary logistic regression analyses to generate risk profiles for each of the following categories of lifetime use: tobacco, alcohol, cannabis, other illicit drugs, and multiple (two or more) other illicit drugs.

Results: We identified statistically significant risk profiles for these different substance categories. All the different risk factor categories contributed variably to the use of gateway drugs (tobacco, alcohol, marijuana, and other illicits), but the multiple use of other illicit drugs was associated primarily with a narrower set of psychopathological (suicidality, irritability, and antisocial problems) and psychosocial variables (family substance abuse and peer influence).

Conclusions: These risk profiles share some commonality with those found amongst other populations. However, these unique risk profiles for Turkish youth can be useful in developing primary and secondary preventive interventions to address the growing substance use and abuse problems. Crosssectional and longitudinal studies, focusing on time trends and risk factors of substance use in youth of emerging countries including Turkey, are needed.

Keywords: Turkish youth, substance abuse, ESPAD, monitoring of the future survey, high school students, risk factors

Bulletin of Clinical Psychopharmacology 2014;24(1):5-14
'Cooper School of Medicine of Rowan University, Camden, New Jersey, USA ${ }^{2}$ Governance of Istanbul, Istanbul, Turkey ${ }^{3}$ St. Elizabeths Hospital, Washington, DC, USA

Address reprint requests to: Andres J. Pumariega, M.D Cooper Health System, 401 Haddon Avenue, Suite 356, Camden, New Jersey, 08103, USA

E-mail address:

Pumariega-Andres@cooperhealth.edu

Date of submission:

March 11, 2014

Date of acceptance: March 17, 2014

\section{Declaration of interest:}

A.J.P., H.B., A.U., P.P., A.D.: The authors reported no conflict of interest related to this article. 


\section{INTRODUCTION}

In industrialized nations, the pre-adolescent and adolescent years have been shown to be the most vulnerable stages of development, and substance abuse constitutes a significant portion of that risk. The risk period for the onset of substance abuse begins in the pre-adolescent period, peaks at 18 to 22 years of age, and displays a decline after age 25 . However, those youth using before age 15 are at the highest risk for chronic substance abuse and dependence ${ }^{1}$. The Monitoring the Future Survey in the United States (U.S.), which from 1992 through to the present has surveyed more than 45,000 eighth graders and high school students, has shown 1.7 million new users per year over the age of 12 and a lifetime prevalence of use of any illicit drug of $25 \%$ for $8^{\text {th }}$ graders and $44 \%$ for $10^{\text {th }}$ graders ${ }^{2}$. The "gateway" phenomenon has been well established, where youth are first introduced to tobacco, alcohol, and cannabis, and then "graduate" to other illicit substances ${ }^{1}$. Adolescent substance abuse is associated with other risky outcomes, including violence, sexual promiscuity, sexually transmitted diseases (including HIV/ AIDS and Hepatitis C), motor vehicle accidents, mortality from overdoses, school failure, depression and suicidality, including completed suicide ${ }^{1}$. These trends are only reinforced by the forces of globalization and social media that glamorize youth culture and substance abuse as a significant aspect of behavior. It is not unreasonable to assert that adolescent substance abuse is perhaps the most important challenge industrialized nations are facing today and it is soon likely to become one for emerging economies, including Turkey.

In order to study the use of alcohol and other drugs among high school students, large amounts of data have been gathered in many countries. The European School Survey Project (ESPAD) ${ }^{3}$, Youth in Europe (YIE) ${ }^{4}$, the Monitoring the Future Survey ${ }^{2}$ and the National Household Survey ${ }^{5}$ (the latter two in the U.S.) are among the most important studies aiming to collect comparable data about alcohol and other drug use among high school students to monitor trends within and also among countries. These surveys have been used to develop profiles and models of risk factors for youth substance abuse, with the potential for guiding prevention and intervention efforts. For example, Kokkevi et al. ${ }^{6}$ studied ESPAD data for 6 European countries for psychosocial correlates of substance abuse in adolescence. High schools in six European countries, Bulgaria, Croatia, Greece, Romania, Slovenia and the UK, were included. They studied representative samples totaling 16,445 high school students whose $16^{\text {th }}$ birthday fell in the year of data collection. They found particularly strong associations between smoking and going out most evenings and having many friends who smoke, while use of cannabis and illegal drugs were strongly correlated with having friends or older siblings who used those substances. They also reported that the self-esteem scale score was not correlated with substance use and anomie and antisocial behavior were more strongly associated than depression with substance use. They provide evidence for the need to address both the use of the gateway drugs and deviant behavior in conjunction with environmental risk factors when designing and implementing preventive interventions in schools.

Turkey has become a regional power in Eurasia with its young population, rapidly growing economy, and historical soft power reaching the Middle East, the Balkans, North Africa, the Caucuses, and many Muslim nations ${ }^{7}$. Istanbul with its 14 million population is the largest city in Turkey and also the major economic, cultural, and tourism destination at the meeting point of three continents. This places Turkey in a geographic and cultural position of experiencing the influences of globalization, which include youth culture and associated increases in substance use and abuse. Hence, developing models about risk factors associated with alcohol and other drugs among high school students in Turkey based on available data are very important not just for Turkish youth, but possibly for youth in many Muslim nations and other developing nations.

Turkey was an original participant in the ESPAD survey. When data from six cities in Turkey 
were compared to the average of all participating countries in ESPAD in 2003, Turkey had lower prevalence on all nine variables ${ }^{8}$. This included use of alcohol during the last 12 months (35\% in Turkey versus $83 \%$ ), lifetime smoking ( $50 \%$ vs $66 \%$ ), lifetime cannabis ( $4 \%$ vs $21 \%$ ), and lifetime use of other illicit drugs except cannabis (3\% vs $6 \%)$. However, there has been a significant trend towards increased substance use and abuse amongst Turkish youth, and investigators have begun to examine possible risk factors for Turkish youth. For example, Unlu and Evcin found that cigarette smoking and alcohol consumption have increased in the Bagcilar province of Istanbul based on their 2008 (2627 students) and 2010 (2150 students) data from high school students (via personal communication). Onal and et al. ${ }^{9}$ studied substance use with attention deficit and hyperactivity symptoms in $10^{\text {th }}$ graders and Corapcioglu and Ogel $^{10}$ investigated factors associated with Ecstasy use in a representative sample of secondary school students in 1998 and 2001. The samples included 18,556 and 11,911 students in 1998 and 2001, respectively. They developed a questionnaire based on the Monitoring the Future and ESPAD studies. They asked questions about demographics, family characteristics, school life, social contacts, and use of substances. The percent of Ecstasy use at least once in a lifetime increased from $2.65 \%$ in 1998 to $3.31 \%$ in 2001 . They found the following variables significant by logistic regression analysis: male gender, older age, use of alcohol, cannabis, heroin, and cocaine, non-medical use of psychotropic medications, and participation in a meeting concerning the adverse effects of substance use.

Our investigative group has analyzed data from a recent survey of substance abuse and significant risk factors amongst high school youth in Istanbul, Turkey. One of us (AJP) had experience as a co-principal investigator in a similar study of youth along the U.S.-Mexican border ${ }^{11,12}$, which is another developing region of the world undergoing rapid change due to globalization. We saw a major opportunity to contribute to the development of risk factor models that could have potential for guiding prevention and early intervention to address this significant problem amongst Turkish youth and other youth in similar cities of the world.

\section{METHODS}

\section{Sampling and Procedures}

The Istanbul Department of Education and Istanbul Police Department collected the data from May to June of 2010, with permission from the Governance of Istanbul. The institutional review board (IRB) of Cooper University Hospital and Ethics Committee of Security Sciences Institute approved the use of the data for the study. Among the 39 provinces in Istanbul, 28 of them (inner cities) were selected for sampling. The schools were divided into three categories in each province, i.e. regular high schools, occupational high schools and Anatolian high schools. The schools were listed alphabetically in each category and every third school was selected from the list starting from A. According to the Education Department of Istanbul (2010), there were 232 normal high schools, 242 occupational high schools, and 88 Anatolian high schools for a total of 562 schools. The sampling design selected 65 normal high schools, 62 occupational high schools, and 27 Anatolian high schools for the study with a total of 154 high schools. The sample represents approximately $20 \%$ of the total school population. Since the unit of analysis of the study was individual adolescents, the population consisted of young people between the ages of 14 and 18 in Istanbul. Systematic sampling was used to select the allocated sample of classrooms. Every third classroom from each grade was included in the sampling. The majority of the population consisted of youth aged 14 to 19 . Ninth graders were the largest student group, and student numbers decrease towards the higher grades among the total student population and in our sample. To sustain the validity and reliability of the survey instruments, a non-existent substance called 
"relevin" was included in the substance list and subjects, who reported the use of this substance were eliminated from the analysis.

\section{Variables, Measures, and Procedures}

The survey instrument used in the study was based on a combination of the European School Survey Project on Alcohol and Other Drugs (ESPAD) and the Youth in Europe Survey (YIE). Both of these surveys have been translated into Turkish and used in many other studies ${ }^{13-15}$. The survey was carried out by trained student counselors. The privacy of respondents was protected by providing students anonymous optic forms and responses were combined by computer.

The dependent variables were measured by five indicators, including the lifetime use of tobacco, alcohol, marijuana, all other illicit drugs (including cocaine, inhalants, opiates, amphetamine, sedative-hypnotics, hallucinogens, steroids, and homemade brews), and use of 2 or more illicit substances ("polyuse"). According to the literature, these substances are the most common substances preferred by Turkish adolescents. Substance use was measured by life time usage with a sevenpoint scale ranging from never-to 40 times or more.

The independent variables included various risk factors that have been demonstrated in the literature to influence adolescent substance abuse. They include:

- Demographic and socio-economic variables (age and gender)

- Socioeconomic status (perceived family income and parental education)

- School variables: These included school type (whether the youth attended Vocational, Regular, or Anatolian high schools) and school grades

- Cultural variables: We constructed a variable that captured the range of nativity in Istanbul (whole family born in Istanbul, one parent born outside Istanbul, both parents born outside Istanbul, or parents and youth born outside Istanbul). This served as a proxy for the degree of cultural orientation towards more traditional versus more Western/ urban culture (the higher the score the more assimilated the family is to Istanbul). We also evaluated adherence to religious faith.

- Psychopathology:

- Depression (as measured by the Centers for Epidemiological Study-Depression scale, CES- $\mathrm{D}^{16}$, higher score denotes higher levels of depression)

- Anxiety Scale (total item score)

- Suicidal ideation (presence in the past week)

- Irritability/Anger Scale (total item score)

- Antisocial behavior (Antisocial Behavior Scale ${ }^{17}$ )

- Psychosocial variables: These include

- Self -esteem Scale (Rosenberg Self-Esteem Scale $^{18}$, higher score denotes higher selfesteem)

- Anomie Scale (Anomie Scale of Exteriority and Constraint ${ }^{19}$, lower score denotes greater anomie)

- Time with Peers (total item score)

- Time with Family (total item score)

- Parental Involvement (total item score)

- Family Substance Use (total item score)

- Peer Influence (total item score)

\section{Analysis}

Total scores were calculated and used for scales (self-esteem, faith, anomie, anxiety, depression, suicidality, and irritability/anger scale). Summative scores were used for other categorical variables (family immigration, perceived family affluence, antisocial personality, time with peers, time with family, parental involvement, family substance use, and peer influence) and for substance use variables. Binary logistic regression was used to analyze the regression models between dependent variables and independent variables (predictors). Level of significance was kept at $p<0.05$. Chi Square coefficients and pseudo $\mathrm{R}$ square values (Nagelkerke $\mathrm{R}$ square) for each model were calculated to analyze the goodness of fit and explain variability of the data. 
Table 1: Gateway Substance Use and Predictor Regression Equations

\begin{tabular}{|c|c|c|c|}
\hline & Independent Variable & P-value & Odds Ratio \\
\hline $\begin{array}{l}\text { Tobacco Use } \\
\text { Chi Square= } 526.855, \\
\text { d.f. }=20, \\
\text { Sig. }<.000, \\
\text { Nagelkerke R square }=.230\end{array}$ & $\begin{array}{l}\text { School Type } \\
\text { Gender } \\
\text { Age } \\
\text { Income } \\
\text { Immigration Status } \\
\text { Self Esteem Scale } \\
\text { Depression Scale } \\
\text { Anomie Scale } \\
\text { Antisocial Traits Scale } \\
\text { Suicidal ideation } \\
\text { Irritability Scale } \\
\text { Faith Scale } \\
\text { Time with Peers } \\
\text { Time with Family } \\
\text { Parental Involvement } \\
\text { Family Substance Use } \\
\text { Peer Influence } \\
\text { Anxiety Scale } \\
\text { School Grades } \\
\text { Parental Education } \\
\text { Constant }\end{array}$ & $\begin{array}{l}0.346 \\
0.312 \\
0.000^{*} \\
0.307 \\
0.313 \\
0.603 \\
0.107 \\
0.003^{*} \\
0.000^{*} \\
0.311 \\
0.000^{*} \\
0.495 \\
0.000^{*} \\
0.000^{*} \\
0.187 \\
0.000^{*} \\
0.000^{*} \\
0.046^{*} \\
0.060 \\
0.024^{*} \\
0.000\end{array}$ & $\begin{array}{l}0.935 \\
0.887 \\
1.570 \\
0.921 \\
0.946 \\
0.994 \\
1.015 \\
0.963 \\
1.139 \\
1.075 \\
1.084 \\
0.995 \\
1.056 \\
0.943 \\
1.009 \\
1.361 \\
0.948 \\
0.937 \\
0.811 \\
0.826 \\
0.000\end{array}$ \\
\hline $\begin{array}{l}\text { Alcohol Use } \\
\text { Chi Square = 1070.004, } \\
\text { d.f.= 20, } \\
\text { Sig. }<.000 \\
\text { Nagelkerke R square }=.341\end{array}$ & $\begin{array}{l}\text { School Type } \\
\text { Gender } \\
\text { Age } \\
\text { Income } \\
\text { Immigration Status } \\
\text { Self Esteem Scale } \\
\text { Depression Scale } \\
\text { Anomie Scale } \\
\text { Antisocial Traits Scale } \\
\text { Suicidal ideation } \\
\text { Irritability Scale } \\
\text { Faith Scale } \\
\text { Time with Peers } \\
\text { Time with Family } \\
\text { Parental Involvement } \\
\text { Family Substance Use } \\
\text { Peer Influence } \\
\text { Anxiety Scale } \\
\text { School Grades } \\
\text { Parental Education } \\
\text { Constant }\end{array}$ & $\begin{array}{l}0.340 \\
0.003^{*} \\
0.000^{*} \\
0.002^{*} \\
0.000^{*} \\
0.018^{*} \\
0.001^{*} \\
0.005^{*} \\
0.046^{*} \\
0.043^{*} \\
0.000^{*} \\
0.000^{*} \\
0.000^{*} \\
0.333 \\
0.001^{*} \\
0.000^{*} \\
0.000^{*} \\
0.077 \\
0.010^{*} \\
0.293 \\
0.000\end{array}$ & $\begin{array}{l}0.948 \\
0.748 \\
1.400 \\
0.807 \\
0.841 \\
0.978 \\
1.027 \\
0.971 \\
1.047 \\
0.878 \\
1.072 \\
0.915 \\
1.063 \\
1.012 \\
1.020 \\
1.512 \\
0.944 \\
0.954 \\
0.789 \\
1.073 \\
0.003\end{array}$ \\
\hline $\begin{array}{l}\text { Cannabis/Marijuana Use } \\
\text { Chi Square= 199.021, } \\
\text { d.f.= 20, } \\
\text { Sig. }<.000 \\
\text { Nagelkerke R square }=.236\end{array}$ & $\begin{array}{l}\text { School Type } \\
\text { Gender } \\
\text { Age } \\
\text { Income } \\
\text { Parental Education } \\
\text { Immigration Status } \\
\text { Self Esteem Scale } \\
\text { Depression Scale } \\
\text { Anomie Scale } \\
\text { Antisocial Traits Scale } \\
\text { Suicidal ideation } \\
\text { Irritability Scale } \\
\text { Faith Scale } \\
\text { Time with Peers } \\
\text { Time with Family } \\
\text { Parental Involvement } \\
\text { Family Substance Use } \\
\text { Peer Influence } \\
\text { Anxiety Scale } \\
\text { School Grades }\end{array}$ & $\begin{array}{l}0.976 \\
0.003^{*} \\
0.004^{*} \\
0.103 \\
0.760 \\
0.700 \\
0.494 \\
0.313 \\
0.010^{*} \\
0.000^{*} \\
0.130 \\
0.263 \\
0.081 \\
0.180 \\
0.504 \\
0.124 \\
0.000^{*} \\
0.000^{*} \\
0.909 \\
0.127\end{array}$ & $\begin{array}{l}0.996 \\
0.463 \\
1.349 \\
1.294 \\
1.009 \\
0.957 \\
0.984 \\
1.019 \\
0.930 \\
1.120 \\
1.222 \\
1.036 \\
0.977 \\
1.038 \\
0.981 \\
1.022 \\
1.285 \\
0.947 \\
0.992 \\
0.703\end{array}$ \\
\hline
\end{tabular}

${ }^{*} \mathrm{p}$-value $<0.05$ is significant 


\section{RESULTS}

The survey participants consisted of 31,272 subjects, who were between ages of 14 and 18 . While $46.6 \%(14,477)$ of the students were male, $53.4 \%(16,581)$ of them were female. Regular high school students constituted $41.9 \%(13,116)$ of the students, while $41.9 \%(13,115)$ of them were in vocational high schools and the rest, $16.1 \%(5,041)$, were in Anatolian high schools. Among these students, $32.4 \%(13,175)$ of them were in $9^{\text {th }}$ grade,
$29.8 \%(9,250)$ were in $10^{\text {th }}$ grade, $25.8 \%(7,988)$ were in 11 th grade and $2 \%(615)$ were in $12^{\text {th }}$ grade. The low involvement of $12^{\text {th }}$ graders was due to absence of the students, who were preparing for national university entrance exam in June. The response rate to the substance named "relevin" was $1.2 \%$ (332) and these subjects were removed from analysis.

Out of the total number of valid responses $(28,303), 13,046$ had engaged in the lifetime use of cigarettes (45.5\%), 9,274 had engaged in alcohol use

Table 2: Any illicit (other than cannabis) and Polyuse Predictor Regression Equations

\begin{tabular}{|c|c|c|c|}
\hline & Independent Variable & P-value & Odds Ratio \\
\hline $\begin{array}{l}\text { Any Illicit Drug Use } \\
\text { (Except Cannabis/ Marijuana) } \\
\text { Chi Square }=1515.173 \\
\text { d.f. }=20 \\
\text { Sig. }<.000 \\
\text { Nagelkerke R square }=.130\end{array}$ & $\begin{array}{l}\text { School Type } \\
\text { Gender } \\
\text { Age } \\
\text { Income } \\
\text { Parental education } \\
\text { Immigration Status } \\
\text { Self Esteem Scale } \\
\text { Depression Scale } \\
\text { Anomie Scale } \\
\text { Antisocial Traits Scale } \\
\text { Irritability Scale } \\
\text { Suicidal ideation } \\
\text { Faith Scale } \\
\text { Time with Peers } \\
\text { Time with Family } \\
\text { Parental Involvement } \\
\text { Family Substance Use } \\
\text { Anxiety Scale } \\
\text { School Grades } \\
\text { Constant }\end{array}$ & $\begin{array}{l}0.771 \\
0.314 \\
0.000^{*} \\
0.879 \\
0.484 \\
0.000^{*} \\
0.588 \\
0.000^{*} \\
0.000^{*} \\
0.000^{*} \\
0.000^{*} \\
0.000^{*} \\
0.000^{*} \\
0.000^{*} \\
0.001^{*} \\
0.000^{*} \\
0.000^{*} \\
0.565 \\
0.001^{*} \\
0.000\end{array}$ & $\begin{array}{l}0.991 \\
0.952 \\
1.176 \\
0.995 \\
1.023 \\
0.900 \\
1.002 \\
1.014 \\
0.972 \\
1.086 \\
1.059 \\
1.281 \\
0.967 \\
1.021 \\
0.981 \\
1.011 \\
1.023 \\
0.993 \\
0.963 \\
0.026\end{array}$ \\
\hline $\begin{array}{l}\text { Polysubstance Use } \\
\text { (any } 2 \text { of } 9 \text { illicit substances other than } \\
\text { Cannabis/Marijuana) } \\
\text { Chi Square }=211.126 \\
\text { d.f. }=20 \\
\text { Sig. }<.000 \\
\text { Nagelkerke R square }=.246\end{array}$ & $\begin{array}{l}\text { School Type } \\
\text { Gender } \\
\text { Age } \\
\text { Parental Education } \\
\text { Income } \\
\text { Immigration Status } \\
\text { Self Esteem Scale } \\
\text { Depression Scale } \\
\text { Anomie Scale } \\
\text { Antisocial Traits Scale } \\
\text { Suicidal ideation } \\
\text { Irritability Scale } \\
\text { Faith Scale } \\
\text { Time with Peers } \\
\text { Time with Family } \\
\text { Parental Involvement } \\
\text { Family Substance Use } \\
\text { Peer influence } \\
\text { Anxiety Scale } \\
\text { School Grades } \\
\text { Constant }\end{array}$ & $\begin{array}{l}0.871 \\
0.240 \\
0.546 \\
0.887 \\
0.226 \\
0.158 \\
0.673 \\
0.072 \\
0.410 \\
0.008^{*} \\
0.000^{*} \\
0.000^{*} \\
0.122 \\
0.063 \\
0.923 \\
0.403 \\
0.000^{*} \\
0.000^{*} \\
0.758 \\
0.319 \\
0.002\end{array}$ & $\begin{array}{l}1.024 \\
0.750 \\
1.065 \\
0.976 \\
1.213 \\
0.856 \\
1.010 \\
0.966 \\
0.979 \\
1.069 \\
1.609 \\
1.157 \\
0.980 \\
1.052 \\
1.003 \\
1.012 \\
1.450 \\
0.946 \\
1.021 \\
0.795 \\
0.000\end{array}$ \\
\hline
\end{tabular}

${ }^{*} \mathrm{p}$-value $<0.05$ is significant 
(32.5\%), 893 had engaged in cannabis (marijuana) use $(3.3 \%)$, and 2,867 had engaged in illicit substance use other than cannabis $(9.2 \%)$. Out of the total sample, 724 youth had engaged in the use of two of any nine illicit substances other than cannabis ("polyuse"; $2.6 \%$ ). It is important to note that these totals were not mutually exclusive insofar as multiple use of tobacco, alcohol, cannabis, and other illicit substances may have occurred.

Tables 1 and 2 summarize the results of the binary logistic regressions for lifetime use of gateway substances (tobacco, alcohol, and cannabis; Table 1), other illicit substances, and polysubstance abuse (defined by the use of any two of nine illicit substances (Table 2). We have reported the significance for each variable (significance level and odds ratio), as well as the significance of each risk factor model and its goodness of fit. The models are all significant and show adequate goodness of fit except for the model for illicit substances, which explains less of the variance in illicit substance use.

For gateway drugs (Table 1), the following variables were significant risk factors: a) Tobacco: demographics (older age), school variables (lower grades), socioeconomic status (lower parental education), psychopathology (lower anxiety, higher irritability, higher antisocial traits), psychosocial variables (higher anomie, more time with peers, less time with family, higher family substance abuse); b) Alcohol: demographics (older age, male gender), school variables (lower grades), socioeconomic status (lower income), cultural variables (lower immigration, lower faith), psychopathology (higher depression, irritability, and antisocial traits and lower suicidality), psychosocial variables (higher anomie, lower selfesteem, greater time with peers, higher parental involvement, higher parental substance abuse, and lower peer influence); c) Cannabis/ Marijuana: demographics (older age, male gender), psychopathology (antisocial traits), and psychosocial variables (higher anomie, lower peer influence, higher family substance use).

For illicit substances other than cannabis (Table 2 ), the significant risk factors in the models were (by category): demographics (older age), school variables (lower school grades), cultural variables (lower immigration, lower faith), psychopathology (higher depression, suicidality, irritability, antisocial traits), psychosocial variables (higher anomie, more time spent with peers, less time spent with family, and greater family substance abuse). For polyuse (use of two or more illicit substances other than cannabis; Table 2), the significant risk factors in the models were (by category): psychopathology (higher suicidality, irritability, and antisocial traits) and psychosocial variables: (lower peer influence, higher family substance abuse).

\section{DISCUSSION}

This study has some limitations. It is important to note that due to the cross-sectional design, the relationships reported between substance use and risk factors were correlational and were not causal. The validity of responses can also be questioned, though precautions were taken to enhance validity (anonymity, the use of the trick substance, use of anonymous and trained counselors). Some risk factors need more specificity since they can cross domains (for example, family substance abuse could be a psychosocial but also a genetic risk factor if it occurred in blood relatives, but there were no specifying data). Additionally, the risk factors reported are only for lifetime use and not more significant use; these are analyses we plan to pursue but may have limited data to accomplish.

There are important lessons to be learned from the results of this study. First of all, the data do support the concerns about a rising problem in adolescent substance use and abuse, especially when the data on illicit substances other than cannabis are compared to those of the 2003 ESPAD Turkish data ${ }^{8}$. The prevalence of lifetime use of gateway drugs amongst Turkish youth is still significantly lower than their Western European and American counterparts, but they appear to be closing the gap in other illicit substances. Second, the patterns of risk factors are strikingly similar to those seen amongst youth in other developing 


\section{RISK FACTORS}

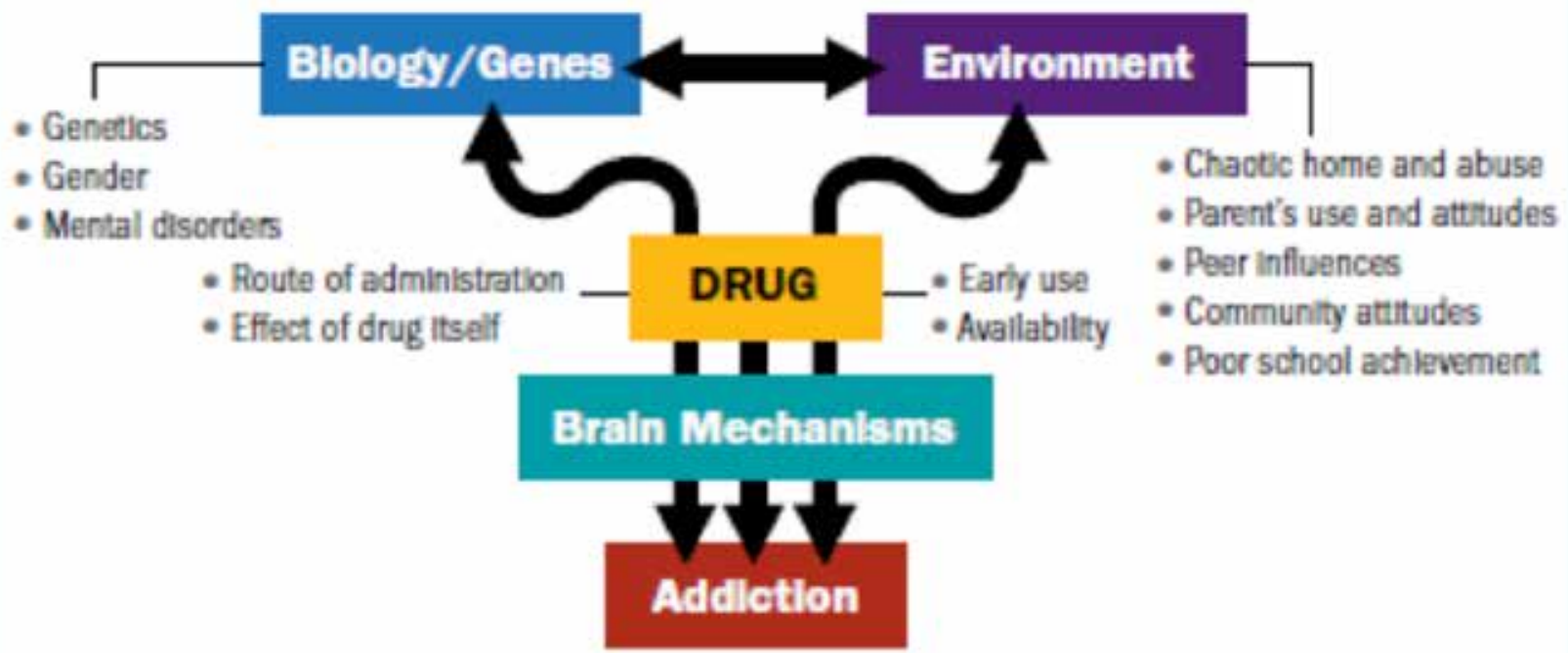

\section{Source: NIDA}

Figure 1: Risk Factor Model for Adolescent Substance Use and Abuse

National Institute of Drug Abuse. Drugs, Brain, and Behavior: The Science of Addiction. NIH Publication Number: 10-5605. Published: April 2007; revised: August 2010. http://www.drugabuse.gov/sites/default/files/sciofaddiction.pdf. Last accessed on 3/2/14.

regions such as the lower Rio Grande Valley along the U.S.-Mexican border, where socioeconomic, cultural transition, psychopathology, and psychosocial factors appear to interact to increase the risk for substance use $\mathrm{e}^{11,12}$. In fact, amongst Turkish youth the cumulative correlation of such variables appears to increase the risk for Turkish youth to move beyond gateway drugs (tobacco, alcohol, and cannabis) and towards other illicit substances. Once youth reach the use of multiple illicit substances, demographic, socioeconomic, and cultural factors appear to play a lesser role, while psychopathology (suicidality, mood disturbance, and antisocial traits) and psychosocial variables (social isolation and higher family substance use) play greater roles.

The development of risk factor models attempts to understand how adolescent substance use and abuse develop and the interplay between biological, psychological, social-demographic, and psychosocial factors (see Figure 1). The ultimate value of such risk factor models is in developing targeted primary and secondary prevention efforts. Typically primary prevention focuses on gateway drugs, while secondary prevention and treatment focus on youth at risk of more serious use. The results of this study suggest that preventive efforts addressing the use of gateway drugs amongst Turkish youth should focus on populations with particular socioeconomic, school, and cultural profiles. Some attention should also be placed on psychosocial and psychopathological risk factors. However, in addressing the critical transition from gateway to illicit drugs there may need to be emphasis on secondary prevention efforts that identify youth at risk of significant psychopathology (mood disturbance, suicidality, and externalizing antisocial behaviors) and psychosocial variables (social isolation and peer and family substance use).

The results also suggest some possible productive strategies. Educators, families, and religious/ faith authorities may be important 
partners in primary and secondary preventive efforts. These efforts may include psychoeducation in schools that address social, cultural, and psychological/ psychosocial risk factors. Family psychoeducation through schools may also be particularly effective, since families see schools as important institutions in their child's life and less stigmatizing than traditional mental health services. It is also important to use cultural strengths as part of primary and secondary preventive interventions, emphasizing traditional Turkish and Muslim cultural and religious strengths. At the same time, religious authorities can contribute to a destigmatizing environment in promoting open discussion about youth substance use and abuse and supporting clinical counseling services where appropriate. There are many models that have accomplished these goals in other nations ${ }^{1,21}$, but they need to be modified to the unique cultural and social context of Turkish society.

Above all, the significance of this study is its reflection of a strong motivation by local agencies and leaders in Istanbul to objectively and scientifically study its increasing youth substance abuse problem. It is commendable that they are taking a proactive stance in openly examining and working to develop their own effective intervention models. Turkey also has a small but developing clinical capacity to treat adolescents with substance abuse in some centers (such as Bakirkoy Psychiatric Training and Research Hospital), but the services need to be expanded towards a community-based model and to more neighborhoods and cities. On the other hand, the growing substance abuse problem in the youth of Turkey needs leadership and collaboration not just among local government agencies, but also coordination among national health, education, and youth authorities, community leaders, and national organizations. Only then Istanbul and Turkey can become leaders in this area and exemplify a forward thinking model in the region that looks to integrate the best of traditional and Western approaches in addressing this critical challenge.

\section{References:}

1. Pumariega AJ, Kilgus MD, Rodriguez L. Adolescence. In: Ruiz P. (Ed.) Lewinsohn's Textbook on Addictions. Philadelphia, PA: Lippincott Williams \& Williams; 2005. Chapter 66, pp 1021-37.

2. O'Malley JL, Bachman JG, Schulenberg JE. Monitoring the Future: National Survey Results on Drug Use. 1975-2011. Volume I: Secondary School Students. Ann Arbor, MI: Institute for Social Research, University of Michigan; 2012.

3. Hibell B, Guttormsson U, Ahlström S, Balakireva O Bjarnason T, Kokkevi A, Kraus L. The 2011 ESPAD Report: Substance Use Among Students in 36 European Countries. Stockholm: The Swedish Council for Information on Alcohol and Other Drugs (CAN), 2012.

http://www.espad.org/Uploads/ESPAD_reports/2011/ The_2011_ESPAD_Report_FULL_2012_10_29.pdf. Last accessed on $3 / 1 / 14$.

4. Youth in Europe Drug Prevention Program. http://www. youthineurope.org/node/2. Last accessed on 3/2/14.

5. Substance Abuse and Mental Health Services Administration, Results from the 2012 National Survey on Drug Use and Health: Mental Health Findings, NSDUH Series H-47, HHS Publication No. (SMA) 13-4805. Rockville, MD: Substance Abuse and Mental Health Services Administration, 2013. http://www.samhsa.gov/data/NSDUH/2k12MH FindingsandDetTables/2K12MHF/NSDUHmhfr2012.pdf.

6. Kokkevi A, Richardson C, Florescu S, Kuzman M, Stergar E. Psychosocial correlates of substance use in adolescence: A cross-national study in six European countries. Drug Alcohol Depend 2007;86(1):67-74. [CrossRef]

7. Green D. A Muslim tiger? Turkey's rising power and influence. OxFam From Poverty to Power. http://oxfamblogs.org/ fp2p/a-muslim-tiger-turkeys-rising-power-and-influence/. Last accessed on 3/1/14.

8. ESPAD: The European School Survey Project on Alcohol and Other Drugs. Turkey (6 cities): Key results 2003. Last edited: 5/21/2012. http://www.espad.org/turkey; last accessed on $2 / 27 / 14$.

9. Onal A, Ogel K, Eke C. A cross-sectional study on substance use and family characteristics of adolescents with attention deficit and hyperactivity symptoms. Klinik Psikofarmakoloji Bulteni- Bulletin of Clinical Psychopharmacology 2011;21: 225-31.

10. Corapcioglu A, Ogel K. Factors associated with Ecstasy use in Turkish students. Addiction 2004;99(1):67-76. [CrossRef]

11. Swanson JW, Linskey AO, Quintero-Salinas R, Pumariega AJ, Holzer CE $3^{\text {rd }}$. A binational school survey of depressive symptoms, drug use, and suicidal ideation. J Am Acad Child Adolesc Psychiatry 1992;31(4):669-78. [CrossRef] 
12. Pumariega AJ, Swanson J, Holzer CE, Linskey AO, and Quintero-Salinas R. Cultural Context and Substance Abuse in Hispanic Adolescents. Journal of Child and Family Studies 1992;1(1):75-92. [CrossRef]

13. Altuner D, Engin N, Gurer C, Akyay I, Akgul A. Substance use and crime: the results of a survey research. The Journal of Medical Investigations 2009;7(2):87-94.

14. Ogel K, Corapcioglu A, Sir-Tamar M, Tot S, Dogan O, Uguz S, et al. Tobacco, alcohol and substance use prevalence among elementary and secondary school students in nine cities of Turkey. Turkish Journal of Psychiatry 2004;15(2):112-8.

15. Ogel K,Tamar D, Evren C, Cakmak D. Prevalence of substance use among high school students in Istanbul. Journal of Clinical Psychiatry 2000;3(4):242-5

16. Radloff, Lenore S. A self-reported Depression Scale for Research in the General Population. Applied Psychological Measurement 1977;1-3:385-401. [CrossRef]

17. Bachman JG, Johnston LD, O'Malley PM. Monitoring the Future: Questionnaire Responses from the Nation's High School Seniors. University of Michigan, Ann Arbor, Michigan, 1982.
18. Rosenberg M. Society and the adolescent self-image. Princeton, NJ: Princeton University Press, 1995.

19. Bjarnason T. Parents, religion and perceived social coherence: a durkheimian framework of adolescent anomie. Journal for the Scientific Study of Religion 1998;37(4):742-54. [CrossRef]

20. Pumariega AJ, Millsaps U, Rodriguez L, Moser M, Pumariega J. Substance Abuse in Immigrant Latino Youth in Appalachia: Preliminary Findings. Addictive Disorders and Their Treatment 2007;6(4):157-65. [CrossRef]

21. National Institute of Drug Abuse. Preventing Drug Abuse Among Children and Adolescents: A Research based Guide for Parents, Educators, and Community Leaders. NIH Publication No. 04-4212(A) Printed 1997. Reprinted 1997, 1999, 2001; Second Edition October 2003. http://www. drugabuse.gov/sites/default/files/preventingdruguse_2.pdf Last accessed on 3/2/14. 